\title{
Breast Cancer cN2b TNM Finding v8
}

National Cancer Institute

\section{Source}

National Cancer Institute. Breast Cancer cN2b TNM Finding v8. NCI Thesaurus. Code C139403.

Breast cancer with metastases only in ipsilateral internal mammary nodes in the absence of axillary lymph node metastases. (from AJCC 8th Ed.) 